\title{
SISTEM PERINGKAS TEKS OTOMATIS MULTI DOKUMEN KLIPING ARTIKEL BERITA GEMPA MENGGUNAKAN METODE TF-IDF
}

\author{
Aa Zezen Zenal Abidin" ${ }^{* 1}$, Enung Nurjanah ${ }^{\# 2}$ \\ Program Studi Teknik Informatika, STMIK Subang ${ }^{* 1}$ \\ Program Studi Teknik Informatika, STMIK Subang ${ }^{\# 2}$ \\ E-mail: zezen2008@yahoo.com ${ }^{* 1}$, enungnurjanah10@gmail.com ${ }^{\# 2}$
}

\begin{abstract}
Abstrak
. Teknologi saat ini berkembang pesat sehingga pengguna internet mudah untuk mengetahui berita yang ada di internet. Berita artikel gempa yang banyak menyulitkan pembaca mengetahui isi berita secara terperinci. Karena itu peringkas teks multi dokumen menjadi penting untuk dilakukan. Agar pembacaan menjadi cepat dan mudah serta informasi bisa di dapat secara singkat. Dengan adanya peringkas teks pembaca bisa mengetahui kliping artikel berita gempa secara singkat tidak hanya dari satu dokumen tetapi beberapa dokumen atau multi dokumen bisa dilakukan, minimal dari dua dokumen. Penulis membuat prototype system peringkas teks multi dokumen menggunakan metode Term frquency inverse document frequency (TF-IDF) yaitu memecah isi dokumen menjadi kalimat, membuang karakter, memecah kalimat menjadi kata, memberi nilai bobot pada kata, menjumlahkan nilai bobot, menghitung nilai idf dan TF-IDF sehingga di dapat nilai bobot kata dari setiap kalimat, diperoleh bobot kalimat dimana bobot yang tertinggi atau beberpa kalimat dengan rangking tertinggi dijadikan ringkasan dari masing-masing dokumen. Ringkasan dari setiap dokumen digabung dan diringkaskan lagi, sehingga menjadi ringkasan ketiga sebagai gabungan dua dokumen. Digunakan tools berbasis web, Bahasa pemogramman yang digunakan yaitu PHP dan DBMS MySQL.

Aplikasi ini dapat mengimplementasikan peringkas teks otomatis multi dokumen kliping artikel berita di internet metode TF-IDF. Sistem ini dapat membantu mengetahui isi penting dari kliping artikel berita yang banyak di internet. Memiliki akurasi hasil uji responden $54.45 \%$ dan uji kemiripan dokumen sebesar 78.023\%.
\end{abstract}

Kata kunci: peringkas teks multi dokumen, kliping artikel berita, $T F-I D F .$.

\begin{abstract}
New technology is increasingly evolving so that internet users can find out the news on the internet quickly. Most news stories about the earthquake make it difficult for readers to know the news contents in depth. Because of this, summarizing multi-document texts is important. So that readings are fast and easy and information can be obtained briefly. With the summarization of the text the reader can know the clippings of earthquake news briefly not only from one document but several documents or multiple documents can be done, at least from two documents. The author constructs a prototype multi-document text summarizing system using the term frequency inverse document frequency $(T F-I D F)$ method for breaking the content of documents into sentences, discarding characters, breaking sentences into words, giving weight values to words, adding weight values, measuring idf and TF values -IDF in order to obtain the word weight value of each sentence, $t$ Each document's summary is merged and summarized again, so as to become the third summary as a combination of two documents. Web-based tools are used, the programming language used is PHP and MySQL DBMS. This application can implement multi-document automatic text summarizing news article clippings on the internet TF-IDF method. This system can help find out the important contents of many news article clippings on the internet. the system has the accuracy of the results of the respondent's test $54.45 \%$ and the similarity test document accuracy is 78,023\%
\end{abstract}

.Key Word: Text summary multi document, clipping ews article, TF-IDF. 


\section{Pendahuluan}

Indonesia merupakan Negara yang berpotensi gempa, berita tentang gempa dari tahun ke tahun sangat banyak. Dengan artikel yang ada pada internet mengakibatkan teknologi saat ini berkembang pesat sehingga berdampak terhadap pengguna internet. Dari internet pengguna bisa mendapatkan informasi kliping artikel berita gempa yang cepat dan akurat. Dengan informasi artikel berita gempa di internet semakin banyak sehingga menyulitkan untuk membaca secara terperinci. Kliping artikel berita gempa yang update dari berbagai media cukup banyak. Oleh karena itu peringkasan teks otomatis multi dokumen menjadi hal yang sangat penting untuk dilakukan. Dengan adanya ringkasan berbentuk kliping, maka dapat menghemat waktu pembaca, mendapatkan informasi dan dapat menghindari pembacaan teks yang tidak relevan dengan informasi yang diharapkan oleh pembaca, terutama ketika sangat banyak informasi tentang artikel berita. Sepengatahuan penulis belum didapatkan aplikasi peringkas teks multi dokumen elektronik kliping.

Meningkatnya pertumbuhan internet telah membuat sejumlah besar informasi tersedia. Sulit bagi manusia untuk merangkum sejumlah besar teks. Dengan demikian, ada kebutuhan yang sangat besar untuk alat summarization otomatis di era kelebihan informasi ini[1]. Dengan adanya peringkas teks kita bisa mengetahui artikel berita gempa secara singkat tidak hanya satu dokumen dengan multi dokumen sekaligus bisa dilakukan, terkadang dengan hanya membaca secara seluruhnya pembaca malas. Dengan peringkas teks pembaca tidak merasa kesulitan.

Dalam tugas akhir ini, penulis menekankan berbagai pendekatan ekstraktif untuk summarization tunggal dan multi-dokumen. Penulis menggambarkan beberapa metode yang paling banyak digunakan seperti pendekatan representasi topik, metode berbasis frekuensi, teknik pembelajaran berbasis grafik dan mesin. Meskipun tidak memungkinkan untuk menjelaskan semua algoritma dan pendekatan yang beragam secara komprehensif dalam tugas akhir ini, penulis berfikir ini memberikan wawasan yang baik mengenai trend terkini dan berkembang dalam metode summarization otomatis dan menggambarkan keadaan mutakhir di area penelitian ini.

Berdasarkan banyak sumber teks yang akan diringkas, peringkasan teks dibagi menjadi dua, yakni peringkasan single document dan peringkasan multi documen[2]. Bahkan dengan banyaknya bahasa di dunia, bisa dilakukan pembuatan resume dokumen tunggal multi bahasa[3], juga multi dokumen dan multi bahasa. Pada single document, sumber ringkasan merupakan dokumen tunggal sedangkan multi document meringkas beberapa sumber dokumen. Selain ringkasan bisa juga sekaligus peringkas dan penerjemahan, misalnya berita dalam bahasa inggris dokumen tunggal diterjemahkan kedalam bahasa Indonesia[4].

\section{Tinjauan Pustaka}

Banyak metode maupun pendekatan yang digunakan untuk melakukan peringkasan teks otomatis. Terdapat dua buah pendekatan dilihat dari teknik pengambilan ringkasan, yaitu ekstraksi dan abstraksi[5]. Di mana ekstraksi merupakan teknik menyeleksi materi dari sumber yang berupa teks sedangkan abstraksi merupakan teknik meringkas teks dengan cara mereformulasikan kembali versi aslinya. Metode TF-IDF merupakan metode yang umum digunakan pada temu kembali informasi[6], metode ini juga terkenal efisien, mudah dan memiliki hasil yang akurat, dimana akan menghitung nilai Term Frequency (TF) dan Inverse Document Frequency (IDF) pada setiap token (kata) di setiap dokumen dalam korpus, Untuk menghitung bobot setiap katat di dokumen d dengan rumus $\mathrm{Wdt}=\mathrm{tfdt} * \mathrm{IDFt}$.

Pembobotan Kalimat berdasarkan Fitur Berita Dan Trending Issue Untuk Peringkasan Multi Dokumen Berita oleh[7] penelitian dengan pembobotan dengan fitur berita mampu memberikan hasil yang lebih akurat, Penelitian terkait yang dilakukan oleh [8]tentang "Peringkas Otomatis Pada Dpkumen Berbahasa Jawa Menggunakan Metode TF-IDF" penelitian menggunakan metode tf-idf menghasilkan akurasi $64 \%$ dan penelitian ini dilakukan untuk minat membaca dokumen berbahasa jawa. Dalam penelitian ini menggunakan metode pembobotan kata dalam sebuah dokumen dilakukan dengan mengalikan nilai Tf dan IDF. Pembobotan diperoleh berdasarkan jumlah kemunculan term dalam kalimat (TF) dan jumlah kemunculan term pada seluruh kalimat dalam 
dokum (IDF). Bobot suatu istilah semakin besar jika istilah tersebut sering muncul dalam suatu dokumen dan semakin kecil jika istilah tersenut muncul dalam banyak dokumen, setelah diperoleh idf berikutnya menghitung bobot $(\mathrm{W})$ masing-masing dokumen[6]:

$$
d f=d 1+d 2+\ldots+d n
$$

Df : Total kata pada term

D : frekuensi kata pada kalimat

$$
\begin{aligned}
& i d f=\log (\mathrm{n} / \mathrm{Df}) \\
& \mathrm{N} \text { : total dokumen } \\
& \text { Df : banyak dokumen yang mengandung kata yang dicari } \\
& \text { d : dokumen ke }-\mathrm{d} \\
& W(t, d)=t f(t, d) * i d f \\
& \text { : kata ke -t dari kata kunci } \\
& \text { : banyaknya kata yang dicari pada sebuah dokumen }
\end{aligned}
$$

\begin{tabular}{|c|c|}
\hline no & kalimat \\
\hline 1 & $\begin{array}{l}\text { TRIBUNNEWS.COM, JAKARTA - Gempa bumi melanda Banten dan Jakarta, Selasa } \\
(23 / 1 / 2018) \text { sekitar pukul 13.35 WIB. }\end{array}$ \\
\hline 2 & $\begin{array}{l}\text { Badan Metereologi dan Geofisika (BMKG) mencatat gempa berkekuatan } 6.4 \text { SR sekitar pukul } \\
\text { 13:34:50 WIB. }\end{array}$ \\
\hline 3 & Dengan pusat lokasi gempa 7.21 LS, 105.91 BT (81 kilometer Barat Daya Lebak Banten). \\
\hline 4 & Adapun kedalaman pusat gempa $10 \mathrm{Km}$. \\
\hline 5 & Gempa juga dirasakan di Jakarta dan sekitarnya. \\
\hline 6 & Di berbagai wilayah Jakarta, sejumlah pihak melaporkan adanya gempa. \\
\hline 7 & Termasuk di kampus Al Azhar Kebayoran Baru Jakarta. \\
\hline 8 & Sejumlah mahasiswa keluar dari kampus begitu gedung bergoyang. \\
\hline 9 & Di Provinsi Banten yang berbatasan dengan Jakarta juga tak luput dari gempa. \\
\hline 10 & $\begin{array}{l}\text { Seorang warga di Kecamatan Pamulang Kota Tangerang Selatan Banten melaporkan gempa } \\
\text { cukup keras menggoyang lantai dua rumahnya. }\end{array}$ \\
\hline 11 & Tadi saya tidur, tempat tidurnya sampai goyang, ujar Julaeha. \\
\hline 12 & $\begin{array}{l}\text { Terjadi } 35 \text { kali gempa susulan setelah gempa utama berkekuatan } 6,1 \text { skala richter dirasakan } \\
\text { warga Banten, termasuk Jakarta, bekasi, Bogor, serta Sumatera bagian selatan, Selasa } \\
(23 / 1 / 2018) \text {. }\end{array}$ \\
\hline 13 & Dua di antaranya terjadi di Lebak, Rabu, (24/1/2018). \\
\hline
\end{tabular}

\section{Analisa dan Pembahasan}

Peringkas teks multi dokumen dalam penelitian ini berasal dari dua dokumen artikel gempa. Dokumen pertama dari Pertama artikel dari Tribunnews.com, ada 10 paragraph, diuraikan menjadi 53 kalimat, seperti diperlihatkan dalam Tabel 1. Dokumen kedua berasal dari artikel berita gempa CNN Indonesia dengan jumlah 9 paragraf dan diuraikan menjadi 48 kalimat, seperti diperlihatkan dalam Tabel 2.

Tabel 1 Daftar 53 kaliamt dari dokumen 1 


\begin{tabular}{|c|c|}
\hline 14 & gannya dirasakan hingga wilayah Serang dan Jakarta. \\
\hline 15 & Gempa susulan ini tidak berpotensi tsunami. \\
\hline 16 & Bahkan kekuatannya pun lebih kecil dibandingkan gempa utama. \\
\hline 17 & $\begin{array}{l}\text { Hal itu diungkapkan oleh Kepala Stasiun Geofisika BMKG Bandung Tony Agus Wijaya } \\
\text { kepada Tribun via sambungan telepon. }\end{array}$ \\
\hline 18 & Dua gempa susulan ini kekuatannya lebih kecil dari gempa utama. \\
\hline 19 & Yang pertama berkekuatan 4.2 SR dan yang kedua 5.1 SR. \\
\hline 20 & Sisanya lebih kecil dari dua gempa susulan itu," lanjutnya. \\
\hline 21 & $\begin{array}{l}\text { Sebelumnya diberitakan, gempa susulan yang dirasakan manusia terjadi pada pukul } 08.49 \\
\text { dengan kekuatan } 4.2 \mathrm{SR} \text {. }\end{array}$ \\
\hline 22 & Pusat gempa berada di $7.15 \mathrm{LS}, 106.08 \mathrm{BT}$ atay 67 kilometer barat daya Lebak, Banten. \\
\hline 23 & Kedalaman gempa sekutar 36 kilimeter. \\
\hline 24 & Sedangkan, gempa kedua, kata Tony, terjadi pada pukul 13.32.46 dengan kekuatan 5.1 SR. \\
\hline 25 & $\begin{array}{l}\text { Pusat gempa berada } 7.16 \mathrm{LS}-106.07 \mathrm{BT} \text { atau } 69 \mathrm{~km} \text { barat daya Lebak, Banten dengan } \\
\text { kedalaman } 42 \text { kilometer. }\end{array}$ \\
\hline 26 & $\begin{array}{l}\text { Badan Meteorologi, Klimatologi, dan Geofisika (BMKG) mencatat hingga saat ini, Rabu } \\
(24 / 1 / 2018) \text {, sudah tercatat } 46 \text { gempabumi susulan terjadi wilayah Banten, Jakarta, dan Jawa } \\
\text { Barat bagian barat. }\end{array}$ \\
\hline 27 & $\begin{array}{l}\text { Gempa bumi ini termasuk dalam gempa susulan Gempabumi Selatan Banten, Selasa } \\
(23 / 1 / 2018) \text { kemarin, dengan kekuatan 6,1 SR. }\end{array}$ \\
\hline 28 & $\begin{array}{l}\text { Hari ini sendiri, BMKG merilis telah terjadi gempabumi tektonik yang terjadi wilayah Banten, } \\
\text { Jakarta, dan Jawa Barat bagian barat Rabu (24/1/2018), pukul 13.32.45 WIB. }\end{array}$ \\
\hline 29 & $\begin{array}{l}\text { Hasil update analisis BMKG menunjukkan bahwa gempabumi berkekuatan } 5,0 \text { SR terjadi } \\
\text { dengan koordinat episenter pada } 7,21 \text { LS dan 105,99 BT. }\end{array}$ \\
\hline 30 & $\begin{array}{l}\text { Atau tepatnya berlokasi di laut pada jarak } 72 \mathrm{~km} \text { Barat Daya Lebak-Banten pada kedalaman } \\
44 \mathrm{~km} \text {, ujar Kepala Pusat Gempabumi dan Tsunami BMKG, Moch Riyadi dalam } \\
\text { keterangannya, Rabu (24/1/2018). }\end{array}$ \\
\hline 31 & $\begin{array}{l}\text { Untuk itu pula, BMKG mengimbau masyarakat agar tetap tenang dan tidak terpengaruh oleh } \\
\text { isu yang tidak dapat dipertanggungjawabkan kebenarannya. }\end{array}$ \\
\hline 32 & $\begin{array}{l}\text { Gempa bumi bermagnitudo } 6,1 \text { yang berpusat di Kabupaten Lebak, Banten, Selasa } \\
(23 / 1 / 2018) \text {, menyebabkan ratusan rumah rusak di kawasan tersebut. }\end{array}$ \\
\hline 33 & $\begin{array}{l}\text { Kepala BPBD Lebak, Banten, Kaprawi mengatakan, ada } 105 \text { rumah rusak di } 7 \text { kecamatan di } \\
\text { Kabupaten Lebak setelah gempa mengguncang. }\end{array}$ \\
\hline
\end{tabular}




\begin{tabular}{|c|c|}
\hline 34 & $\begin{array}{l}\text { Petugas kami terus mendata di lapangan, kami dibantu tokoh masyarakat, TNI/Polri, dan } \\
\text { warga, ucap Kaprawi dalam wawancara dengan KompasTV, Selasa. }\end{array}$ \\
\hline 35 & $\begin{array}{l}\text { Data terbaru Kompas TV menunjukkan, kerusakan rumah paling banyak terjadi di Kecamatan } \\
\text { Panggarangan, yaitu } 85 \text { rumah. }\end{array}$ \\
\hline 36 & Kerusakan umumnya terjadi di bagian atap. \\
\hline 37 & $\begin{array}{l}\text { Sebelumnya, data sementara yang diperoleh dari BPBD Lebak, setidaknya sudah } 45 \text { rumah } \\
\text { rusak, yaitu masing-masing } 3 \text { rumah di Kecamatan Bayah, } 1 \text { rumah di Kecamatan } \\
\text { Wanasalam, } 32 \text { rumah di Kecamatan Panggarangan, } 6 \text { rumah di Kecamatan Cilograng, } 1 \\
\text { rumah di Kecamatan Lebak Gedong, dan } 2 \text { rumah di Kecamatan Sobang. }\end{array}$ \\
\hline 38 & Untuk sementara pula, belum ada laporan korban jiwa. \\
\hline 39 & BPBD Lebak masih terus mendata kerusakan dan korban setelah guncangan gempa ini. \\
\hline 40 & $\begin{array}{l}\text { Tim Tanggap Bencana Dewan Pimpinan Pusat Arus Bawah Jokowi (DPP ABJ) memberikan } \\
\text { bantuan kemanusiaan kepada korban bencana gempa bumi di Kabupaten Lebak, Banten. }\end{array}$ \\
\hline 41 & Bantuan diserahkan langsung oleh pengurus ABJ kepada warga yang membutuhkan. \\
\hline 42 & $\begin{array}{l}\text { Sebagai bentuk kepedulian kepada sesama, hari ini relawan Jokowi (ABJ) menyerahkan } \\
\text { bantuan berupa keperluan yang dibutuhkan warga korban gempa Lebak, terang Ketua Umum } \\
\text { Dewan Pengurus Pusat Arus Bawah Joko Widodo (DPP ABJ) Veldy Reynold dalam } \\
\text { keterangannya, Sabtu (27/1/2018). }\end{array}$ \\
\hline 43 & $\begin{array}{l}\text { Disampaikan, bantuan yang diberikan kepada warga itu berupa paket sembilan bahan pokok } \\
\text { (Sembako) seperti beras, minyak goreng, telur serta kebutuhan yang sangat diperlukan warga } \\
\text { lainnya. }\end{array}$ \\
\hline 44 & Dari perlengkapan bayi dan susu bayi, alat mandi, selimut, tikar dan obat-obatan untuk warga. \\
\hline 45 & $\begin{array}{l}\text { Semoga bantuan inI dapat meringankan beban saudara-saudara kita di Lebak yang terkena } \\
\text { musibah, semoga warga bisa segera kembali beraktivitas segera biasa, jelas Veldy. }\end{array}$ \\
\hline 46 & $\begin{array}{l}\text { Bantuan kemanusiaan, lanjutnya, diberikan kepada warga di Desa Ciladeun dan Desa Citorek } \\
\text { Lebak Gedong serta Desa Gunung Batu di Kecamatan Cilograng. }\end{array}$ \\
\hline 47 & $\begin{array}{l}\text { Ditekankan pula bahwa aksi sosial ABJ tersebut untuk melatih kepedulian sosial relawan } \\
\text { Jokowi dari berbagai daerah terhadap kondisi sosial kemasyarakatan yang sering terjadi. }\end{array}$ \\
\hline 48 & $\begin{array}{l}\text { Kata Veldy, menjaga dan memperhatikan kondisi masyarakat adalah bagian terpenting dari } \\
\text { gerakan sosial kemasyarakatan yang dijalankan ABJ. }\end{array}$ \\
\hline
\end{tabular}




\begin{tabular}{|c|l|}
49 & $\begin{array}{l}\text { Salah satunya dengan mengulurkan tangan kepada saudara-saudara kita yang mengalami } \\
\text { bencana. }\end{array}$ \\
\hline 50 & $\begin{array}{l}\text { Untuk diketahui, gempa bumi berkekuatan 6,1 SR mengguncang Jakarta dan sekitarnya } \\
\text { berpusat di Kabupaten Lebak, Banten, Selasa 23 Januari 2018. }\end{array}$ \\
\hline 51 & $\begin{array}{l}\text { Titik gempa terletak di koordinat 7,21 Lintang Selatan dan 105,91 Bujur Timur atau tepatnya } \\
\text { di } 81 \text { kilometer arah barat Lebak. }\end{array}$ \\
\hline 52 & $\begin{array}{l}\text { Sebanyak 129 rumah rusak akibat bencana tersebut, yakni di 10 Kecamatan masing-masing } \\
\text { di Kecamatan Bayah, Wanasalam, Cilograng, Panggarangan, Lebak Gedong, Sobang, } \\
\text { Cimarga, Sajira, Cihara, dan Rinten. }\end{array}$ \\
\hline 53 & $\begin{array}{l}\text { Selain di Lebak, tercatat ada 13 unit rumah mengalami kerusakan yang berlokasi di Kelurahan } \\
\text { Tari Kolot, Pekancilan dan Kuta di Kabupaten Bogor. }\end{array}$ \\
\hline
\end{tabular}

Tabel 2 Daftar 48 kaliamt dari dokumen 1

\begin{tabular}{|c|l|}
\hline NO & \multicolumn{1}{|c|}{ KALIMAT } \\
\hline 1 & $\begin{array}{l}\text { Jakarta, CNN Indonesia - Gempa 5,2 SR yang melanda Jakarta hari ini merupakan gempa } \\
\text { yang ke-47 kali sejak gempa 6,1 SR terjadi pada 23 Januari 2018 lalu. }\end{array}$ \\
\hline 2 & Hal itu dianggap sebagai hal normal sebelum pergerakan lempeng kembali stabil. \\
\hline 3 & $\begin{array}{l}\text { Dari kemarin sejak gempa pertama sudah 47 kali, tapi makin lama makin kecil, kata Kepala } \\
\text { Badan Penanggulangan Bencana Daerah (BPBD) Kabupaten Lebak, Kaprawi, Jumat (26/1). }\end{array}$ \\
\hline 4 & $\begin{array}{l}\text { Gempa teranyar terjadi pada pukul 11:48 WIB siang tadi dengan pusat gempa di 79 kilometer } \\
\text { barat daya Lebak, Banten, dan kedalaman 11 km. }\end{array}$ \\
\hline 5 & $\begin{array}{l}\text { Beberapa hari terakhir sejak 23 Januari kemarin, gempa susulan terus terjadi. } \\
\text { Badan Meteorologi Kimatologi dan Geofisika (BMKG) menyebut gempa bumi terjadi akibat } \\
\text { aktivitas subduksi lempeng Indo-Australia ke bawah lempeng Eurasia. }\end{array}$ \\
\hline 7 & $\begin{array}{l}\text { Kepala Humas BMKG Hary Tirto Djatmiko menganggap banyaknya gempa susulan yang } \\
\text { terjadi belakangan sebagai hal yang wajar. }\end{array}$ \\
\hline 8 & $\begin{array}{l}\text { Biasanya, setelah sebuah gempa bumi yang cukup besar terjadi, gempa susulan bakal terus } \\
\text { mengguncang dengan kekuatan yang lebih lemah. }\end{array}$ \\
\hline 9 & $\begin{array}{l}\text { Sebelum terjadi kestabilan memang akan diikuti gempa susulan, ucap Tirto saat dihubungi } \\
\text { terpisah lewat sambungan telepon. }\end{array}$ \\
\hline 10 & $\begin{array}{l}\text { Tirto juga menjelaskan masyarakat tak perlu khawatir berlebih ketika merasakan gempa } \\
\text { susulan karena durasinya lebih singkat. }\end{array}$ \\
\hline 11 & $\begin{array}{l}\text { Ketika gempa pertama terjadi pada Selasa (23/1), durasinya guncangannya dilaporkan } \\
\text { mencapai semenit. }\end{array}$ \\
\hline 6
\end{tabular}




\begin{tabular}{|c|c|}
\hline 12 & $\begin{array}{l}\text { Sementara di gempa siang tadi, menurut BMKG, guncangannya hanya terasa tiga detik di } \\
\text { Lebak dan sedetik saja di Jakarta. }\end{array}$ \\
\hline 13 & $\begin{array}{l}\text { Badan penanggulangan bencana PBB, UNISDR, sebelumnya menerbitkan sebuah } \\
\text { pemberitahuan melalui kanal Twitter mereka pada Selasa }(23 / 1) \text {. }\end{array}$ \\
\hline 14 & Dalam pengumuman itu mereka menyebutkan bahwa Cincin Api Pasifik sedang aktif. \\
\hline 15 & $\begin{array}{l}\text { Kesimpulan itu diambil dari sejumlah kejadian yang terjadi di sejumlah negara dihari yang } \\
\text { sama, yakni gempabumi 7,9 SR di Alaska, erupsi vulkanis di Filipina, longsor vulkanis di } \\
\text { Jepang, dan terakhir gempabumi 6,1 SR di Lebak, Namun Tirto menampik kemungkinan } \\
\text { tersebut. }\end{array}$ \\
\hline 16 & $\begin{array}{l}\text { Menurutnya kejadian yang terjadi di tempat lain tak berakibat langsung terhadap gempa di } \\
\text { Lebak. }\end{array}$ \\
\hline 17 & Beda lempeng, beda lokasi, beda penyebab, enggak ada kaitannya langsung, pungkas Tirto. \\
\hline 18 & Jumlah rumah rusak akibat gempa bumi, hingga sore tadi, telah terdata sebanyak 490 unit. \\
\hline 19 & Jumlah rumah rusak berat berada di Kecamatan Cilograng, mencapai 42 unit. \\
\hline 20 & Lalu di Kecamatan Bayah berjumlah 23 unit. \\
\hline 21 & Kerusakan rumah, belum termasuk sekolah. \\
\hline 22 & $\begin{array}{l}\text { Pertama kita selamatkan jiwanya dulu, sekarang kita berikan bantuan logistic, kata Bupati } \\
\text { Lebak, itu Octavia Jayabaya, saat dikonfirmasi melalui sambungan teleponnya, Selasa } \\
(23 / 01 / 2018) \text {. }\end{array}$ \\
\hline 23 & Dapur umum pun telah didirikan Pemkab Lebak. \\
\hline 24 & $\begin{array}{l}\text { Tujuannya, untuk menyediakan kebutuhan makanan dan minuman bagi korban gempa bumi } \\
\text { berkekuatan } 6,1 \mathrm{SR} \text {. }\end{array}$ \\
\hline 25 & $\begin{array}{l}\text { Dapur umum di tiap titik sulit, kita sebar, karena di setiap desa dan kecamatan, kita juga punya } \\
\text { relawan Lebak tangguh. }\end{array}$ \\
\hline 26 & Pengungsi belum ada. \\
\hline 27 & Dapur umum di Bayah, Cilograng, jelasnya. \\
\hline 28 & Meski begitu, pemerintah belum mendirikan tenda pengungsian. \\
\hline 29 & $\begin{array}{l}\text { Lantaran warga terdampak gempa, telah mengungsi ke rumah saudara maupun tetangganya } \\
\text { yang tidak mengalami kerusakan. }\end{array}$ \\
\hline 30 & Alhamdulillah rumah masih bisa ditempati. \\
\hline 31 & Kalau rusak berat, mereka mengungsi di rumah saudara dan tetangganya, terangnya. \\
\hline
\end{tabular}




\begin{tabular}{|c|c|}
\hline 32 & $\begin{array}{l}\text { Berdasarkan informasi yang dihimpun, rumah warga di Kecamatan Bayah dan Cilograng } \\
\text { mengalami pecah kaca, atap hingga tembok ambruk, akibat kencangnya gempa yang } \\
\text { menggoyang wilayah Kabupaten Lebak, Banten. }\end{array}$ \\
\hline 33 & $\begin{array}{l}\text { Presiden Joko Widodo melalui Menteri Sosial Idrus Marham telah menyalurkan bantuan bagi } \\
\text { korban gempa bumi Lebak, Banten. }\end{array}$ \\
\hline 34 & $\begin{array}{l}\text { Presiden memberikan bahan makanan, selimut, tenda, alat makan, hingga santunan kepada } \\
\text { ahli waris. }\end{array}$ \\
\hline 35 & $\begin{array}{l}\text { Dari semalam kami sudah berkoordinasi dengan pihak provinsi maupun kabupaten untuk } \\
\text { memberikan bantuan, kata Idrus melalui pernyataannya ke media, Rabu }(24 / 1) \text {. }\end{array}$ \\
\hline 36 & Arahan pak Presiden itu, harus dilihat langsung seperti apa [kondisinya]. \\
\hline 37 & Pokoknya pastikan tidak ada anak bangsa yang tak terurus, lanjutnya. \\
\hline 38 & $\begin{array}{l}\text { Idrus memberikan bantuan langsung tersebut secara simbolis kepada Bupati Lebak, itu } \\
\text { Octavia Jayabaya. }\end{array}$ \\
\hline 39 & $\begin{array}{l}\text { Itu mengingatkan kepada masyarakat untuk tetap waspada atas kemungkinan gempa bumi } \\
\text { susulan. }\end{array}$ \\
\hline 40 & $\begin{array}{l}\text { Di sisi lain, Pemprov Banten juga telah menyalurkan bantuan berupa beras, selimut, matras, } \\
\text { bahan pangan, tenda, dan bantuan lainnya dengan nilai mencapai } R p 230 \text { juta. }\end{array}$ \\
\hline 41 & $\begin{array}{l}\text { Pun, Wakil Gubernur Banten Andika Hazrumy menyatakan tenaga relawan sudah siap } \\
\text { membantu masyarakat Lebak menangani dampak dari gempa bumi Selasa }(23 / 1) \text {. }\end{array}$ \\
\hline 42 & $\begin{array}{l}\text { Teman relawan dari Tagana sudah ada } 215 \text { personil yang siap di Kabupaten Lebak dan } 40 \\
\text { personil lainnya dari Kabupaten Lebak, kata Andika. }\end{array}$ \\
\hline 43 & $\begin{array}{l}\text { Bantuan untuk korban gempa bumi Lebak juga datang dari Polda Banten yang memberikan } \\
\text { aneka bahan pangan, mulai dari beras, gula, telur, hingga bumbu dapur, biskuit, dan mi instan. }\end{array}$ \\
\hline 44 & $\begin{array}{l}\text { Selain bantuan bahan pangan, Polda Banten pun menerjunkan satu kompi Brimob dan satu } \\
\text { peleton shabara untuk membantu warga terdampak gempa bumi. }\end{array}$ \\
\hline 45 & $\begin{array}{l}\text { Menurut data dari Korem 064/Maulana Yusuf, terdapat satu korban jiwa atas tragedi gempa } \\
\text { 6,1 SR di Lebak. }\end{array}$ \\
\hline 46 & $\begin{array}{l}\text { Korban bernama Nama Karyana, berusia } 40 \text { tahun, merupakan warga Kampung Cikaung, } \\
\text { Desa Sawarna, Kecamatan Bayah. }\end{array}$ \\
\hline 47 & $\begin{array}{l}\text { Sedangkan korban luka berat diketahui berjumlah satu orang bernama Ulum, } 62 \text {, yang } \\
\text { mengalami patah tulang. }\end{array}$ \\
\hline
\end{tabular}


$48 \quad$ Ia merupakan warga Desa Cilograng, Kecamatan Bayah, Kabupaten Lebak.

Setelah mendapatkan daftar kalimat dalam dokumen beberapa paragrafh yang di dapat, maka tahap selanjutnya yaitu melakukan proses preprocessing. Pertama melakukan proses case folding atau menghapus tanda baca, kedua yaitu stopword mengahapus kata yang tidak pantas atau kata penghubung, kata konjungsi, kata bantu, dll. ketiga yaitu tokenizing merubah huruf besar menjadi huruf kecil dan merubah huruf menjadi kata dasar itu sendiri. Setelah itu menghitung Nilai $\mathrm{DF}$, penulis hanya mengambil 7 kalimat dan 11 kata untuk tampilan di publikasi ini seperti diperlihatkan pada Tabel 3 dari Artikel Tribunnews.com : Kata berjumlah 305 kata dan kalimat berjumlah 53 kalimat pada Tabel 3. Artikel CNN Indonesia : Kata berjumlah 305 kata dan kalimat berjumlah 48 kalimat pada Tabel 4 diambil 10 kata dan 7 kalimat. Bobot kata yang sekaligus dapat digunakan dalam menghitung bobot kalimat diperlihatkan dalam Tabel 5, bobot kata dan sekaligus berikutnya bobot kalimat diperlihatkan dalam Tabel 6 .

Tabel 3 Proses perhitungan TF dan IDF Tribunnews.com

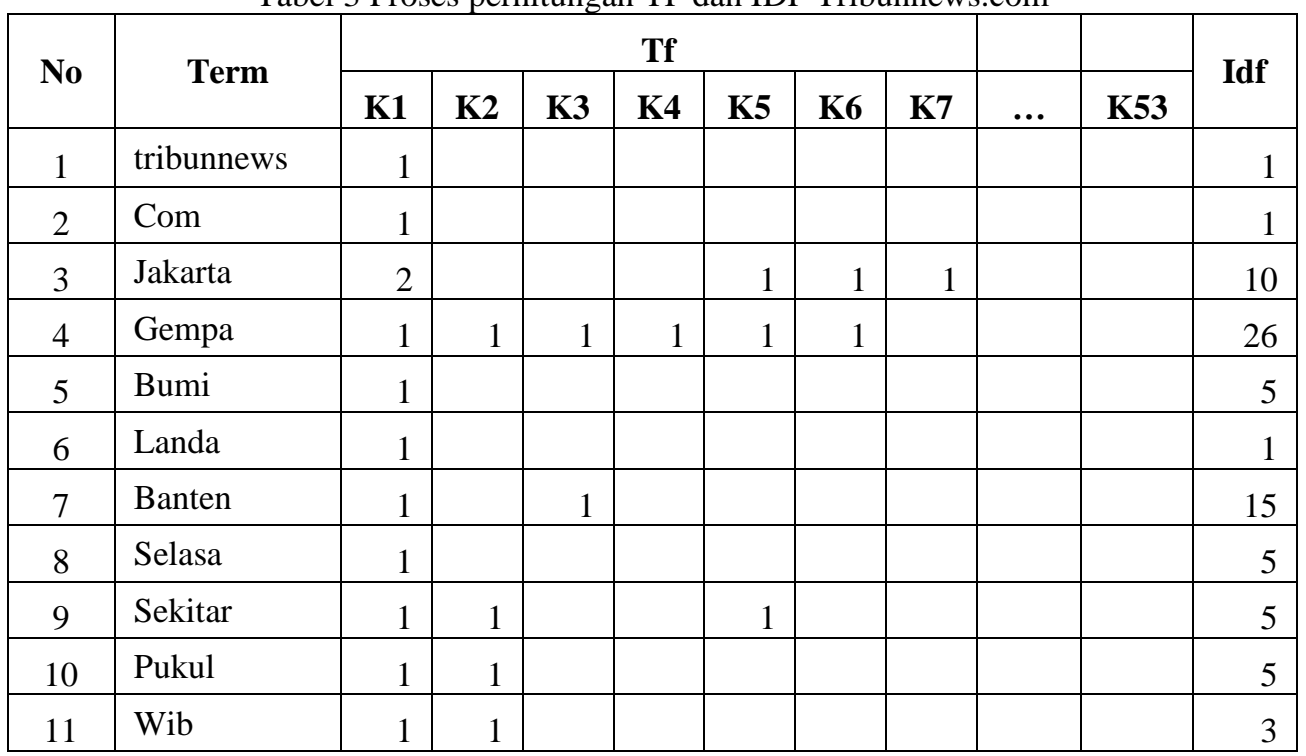

Tabel 4 Proses perhitungan TF dan IDF CNN Indonesia

\begin{tabular}{|r|l|r|r|r|r|r|r|r|r|r|r|}
\hline \multirow{2}{*}{ No } & \multirow{2}{*}{ Term } & \multicolumn{7}{|c|}{ TF } & \multicolumn{1}{|c|}{ Idf } \\
\cline { 3 - 13 } & & K1 & K2 & K3 & K4 & K5 & K6 & K7 & $\ldots$ & 48 & \\
\hline 1 & Jakarta & 2 & 0 & 0 & 0 & 0 & 0 & 0 & & & 2 \\
\hline 2 & Cnn & 1 & 0 & 0 & 0 & 0 & 0 & 0 & & & 1 \\
\hline 3 & indonesia & 1 & 0 & 0 & 0 & 0 & 0 & 1 & & 2 & 2 \\
\hline 4 & Gempa & 3 & 0 & 1 & 2 & 1 & 1 & 0 & & & 21 \\
\hline 5 & Sr & 2 & 0 & 0 & 0 & 0 & 0 & 0 & & & 4 \\
\hline 6 & landa & 1 & 0 & 0 & 0 & 0 & 0 & 0 & & & 1 \\
\hline 7 & Hari & 1 & & & & 1 & & & & & 3 \\
\hline 8 & Kali & 1 & & 1 & & & & & & & 2 \\
\hline 9 & Terjadi & 1 & & & 1 & 1 & 1 & 1 & & & 10 \\
\hline
\end{tabular}


Tabel 5 Proses Perhitungan wdt (bobot kata) artikel Tribunnews.com

\begin{tabular}{|r|c|r|r|r|r|r|r|r|r|}
\hline \multicolumn{1}{|c|}{ Idf } & \multicolumn{10}{|c|}{ wdt=tf.idf } \\
\hline $\log (\mathbf{n} / \mathbf{d f})$ & \multicolumn{1}{c|}{ K1 } & \multicolumn{1}{c|}{ K2 } & \multicolumn{1}{c|}{ K3 } & \multicolumn{1}{c|}{ K4 } & \multicolumn{1}{c|}{ K5 } & \multicolumn{1}{c|}{ K6 } & K7 & $\ldots$ & \multicolumn{1}{|c|}{ K53 } \\
\hline 1.724 & 1.724 & 0 & 0 & 0 & 0 & 0 & 0 & & 0 \\
\hline 1.724 & 1.724 & 0 & 0 & 0 & 0 & 0 & 0 & & 0 \\
\hline 0.724 & 1.449 & 0 & 0 & 0 & 0.7243 & 0.7243 & 0.7243 & & 0 \\
\hline 0.309 & 0.309 & 0.309 & 0.3093 & 0.3093 & 0.3093 & 0.3093 & 0 & & 0 \\
\hline 1.025 & 1.025 & 0 & 0 & 0 & 0 & 0 & 0 & & 0 \\
\hline 1.724 & 1.724 & 0 & 0 & 0 & 0 & 0 & 0 & & 0 \\
\hline 0.548 & 0.548 & 0 & 0.5482 & 0 & 0 & 0 & 0 & & 0 \\
\hline 1.025 & 1.025 & 0 & 0 & 0 & 0 & 0 & 0 & & 0 \\
\hline 1.025 & 1.025 & 1.025 & 0 & 0 & 1.0253 & 0 & 0 & & 0 \\
\hline 1.025 & 1.025 & 1.025 & 0 & 0 & 0 & 0 & 0 & & 0 \\
\hline 1.247 & 1.247 & 1.247 & 0 & 0 & 0 & 0 & 0 & & 0 \\
\hline
\end{tabular}

Tabel 6 Proses perhitungan wdt artikel CNN Indonesia

\begin{tabular}{|c|c|c|c|c|c|c|c|c|c|}
\hline Idf & \multicolumn{10}{|c|}{ wdt=tf.idf } \\
\hline $\log (\mathbf{n} / \mathbf{d f})$ & $\mathbf{K 1}$ & $\mathbf{K 2}$ & $\mathbf{K 3}$ & $\mathbf{K 4}$ & $\mathbf{K 5}$ & $\mathbf{K 6}$ & $\mathbf{K} 7$ & $\mathbf{\cdots}$ & $\mathbf{K 4 8}$ \\
\hline 1.380 & 2.760 & 0 & 0 & 0 & 0 & 0 & 0 & & 0 \\
\hline 1.681 & 1.681 & 0 & 0 & 0 & 0 & 0 & 0 & & 0 \\
\hline 1.380 & 1.380 & 0 & 0 & 0 & 0 & 0 & 0 & & 2.760 \\
\hline 0.359 & 1.077 & 0 & 0.359 & 0.718 & 0.359 & 0.359 & 0.359 & & 0 \\
\hline 1.079 & 2.158 & 0 & 0 & 0 & 0 & 0 & 0 & & 0 \\
\hline 1.681 & 1.681 & 0 & 0 & 0 & 0 & 0 & 0 & & 0 \\
\hline 1.204 & 1.204 & 0 & 0 & 0 & 1.204 & 0 & 0 & & 0 \\
\hline 1.380 & 1.380 & 0 & 1.380 & 0 & 0 & 0 & 0 & & 0 \\
\hline 1.079 & 1.079 & 0 & 0 & 0 & 0 & 0 & 0 & & 0 \\
\hline 1.380 & 1.380 & 0 & 0 & 0 & 1.380 & 0 & 0 & & 0 \\
\hline
\end{tabular}

Hasil perhitungan bobot kalimat dari dokumen pertama digunakan untuk memperoleh ringkasan dari dokumen pertama, dan bobot kaliamt dari dokumen kedua digunakan untuk mendapatkan ringkasan dari dokumen kedua. Kalaimat hasi ringkasan dari dokumen pertama dan dokumen kedua dari paragrafnya masing-masing kemudian dipeoleh semua kaliamt hasil ringkasan seperti pada Tabel 7.

Tabel 7 Daftar kalimat hasil ringkas multi dokumen

\begin{tabular}{|c|c|l|}
\hline $\begin{array}{c}\text { No } \\
\text { Kalimat }\end{array}$ & Paragraf & \multicolumn{1}{c|}{ Kalimat } \\
\hline K1 & P2 & $\begin{array}{l}\text { Terjadi 35 kali gempa susulan setelah gempa utama berkekuatan 6,1 skala richter } \\
\text { dirasakan warga Banten, termasuk Jakarta, bekasi, Bogor, serta Sumatera bagian } \\
\text { selatan, Selasa (23/1/2018). }\end{array}$ \\
\hline K2 & P4 & $\begin{array}{l}\text { Badan Meteorologi, Klimatologi, dan Geofisika (BMKG) mencatat hingga saat ini, } \\
\text { Rabu (24/1/2018), sudah tercatat 46 gempabumi susulan terjadi wilayah Banten, } \\
\text { Jakarta, dan Jawa Barat bagian barat. }\end{array}$ \\
\hline
\end{tabular}




\begin{tabular}{|c|c|c|}
\hline K3 & P4 & $\begin{array}{l}\text { Di sisi lain, Pemprov Banten juga telah menyalurkan bantuan berupa beras, selimut, } \\
\text { matras, bahan pangan, tenda, dan bantuan lainnya dengan nilai mencapai Rp } 230 \\
\text { juta. }\end{array}$ \\
\hline $\begin{array}{c}\text { No } \\
\text { Kalimat }\end{array}$ & Paragraf & Kalimat \\
\hline K4 & P4 & $\begin{array}{l}\text { Hasil update analisis BMKG menunjukkan bahwa gempabumi berkekuatan 5,0 SR } \\
\text { terjadi dengan koordinat episenter pada 7,21 LS dan 105,99 BT. }\end{array}$ \\
\hline K5 & P4 & $\begin{array}{l}\text { Atau tepatnya berlokasi di laut pada jarak } 72 \mathrm{~km} \text { Barat Daya Lebak-Banten pada } \\
\text { kedalaman } 44 \mathrm{~km} \text {, ujar Kepala Pusat Gempabumi dan Tsunami BMKG, Moch } \\
\text { Riyadi dalam keterangannya, Rabu (24/1/2018). }\end{array}$ \\
\hline K6 & P6 & $\begin{array}{l}\text { Sebelumnya, data sementara yang diperoleh dari BPBD Lebak, setidaknya sudah } \\
45 \text { rumah rusak, yaitu masing-masing } 3 \text { rumah di Kecamatan Bayah, } 1 \text { rumah di } \\
\text { Kecamatan Wanasalam, } 32 \text { rumah di Kecamatan Panggarangan, } 6 \text { rumah di } \\
\text { Kecamatan Cilograng, } 1 \text { rumah di Kecamatan Lebak Gedong, dan } 2 \text { rumah di } \\
\text { Kecamatan Sobang. }\end{array}$ \\
\hline K7 & P7 & $\begin{array}{l}\text { Tim Tanggap Bencana Dewan Pimpinan Pusat Arus Bawah Jokowi (DPP ABJ) } \\
\text { memberikan bantuan kemanusiaan kepada korban bencana gempa bumi di } \\
\text { Kabupaten Lebak, Banten. }\end{array}$ \\
\hline K8 & P7 & $\begin{array}{l}\text { Sebagai bentuk kepedulian kepada sesama, hari ini relawan Jokowi (ABJ) } \\
\text { menyerahkan bantuan berupa keperluan yang dibutuhkan warga korban gempa } \\
\text { Lebak, terang Ketua Umum Dewan Pengurus Pusat Arus Bawah Joko Widodo } \\
\text { (DPP ABJ) Veldy Reynold dalam keterangannya, Sabtu }(27 / 1 / 2018) \text {. }\end{array}$ \\
\hline K9 & P8 & $\begin{array}{l}\text { Disampaikan, bantuan yang diberikan kepada warga itu berupa paket sembilan } \\
\text { bahan pokok (Sembako) seperti beras, minyak goreng, telur serta kebutuhan yang } \\
\text { sangat diperlukan warga lainnya. }\end{array}$ \\
\hline K10 & P8 & $\begin{array}{l}\text { Semoga bantuan ini dapat meringankan beban saudara-saudara kita di Lebak yang } \\
\text { terkena musibah, semoga warga bisa segera kembali beraktivitas segera biasa, jelas } \\
\text { Veldy. }\end{array}$ \\
\hline K11 & P9 & $\begin{array}{l}\text { Ditekankan pula bahwa aksi sosial ABJ tersebut untuk melatih kepedulian sosial } \\
\text { relawan Jokowi dari berbagai daerah terhadap kondisi sosial kemasyarakatan yang } \\
\text { sering terjadi. }\end{array}$ \\
\hline K12 & P10 & $\begin{array}{l}\text { Titik gempa terletak di koordinat 7,21 Lintang Selatan dan 105,91 Bujur Timur } \\
\text { atau tepatnya di } 81 \text { kilometer arah barat Lebak. }\end{array}$ \\
\hline
\end{tabular}




\begin{tabular}{|c|c|c|}
\hline K13 & P10 & $\begin{array}{l}\text { Sebanyak } 129 \text { rumah rusak akibat bencana tersebut, yakni di } 10 \text { Kecamatan } \\
\text { masing-masing di Kecamatan Bayah, Wanasalam, Cilograng, Panggarangan, } \\
\text { Lebak Gedong, Sobang, Cimarga, Sajira, Cihara, dan Rinten. }\end{array}$ \\
\hline K14 & P1 & $\begin{array}{l}\text { Jakarta, CNN Indonesia - Gempa 5,2 SR yang melanda Jakarta hari ini merupakan } \\
\text { gempa yang ke-47 kali sejak gempa 6,1 SR terjadi pada } 23 \text { Januari } 2018 \text { lalu. }\end{array}$ \\
\hline K15 & P1 & $\begin{array}{l}\text { Dari kemarin sejak gempa pertama sudah } 47 \text { kali, tapi makin lama makin kecil, } \\
\text { kata Kepala Badan Penanggulangan Bencana Daerah (BPBD) Kabupaten Lebak, } \\
\text { Kaprawi, Jumat (26/1). }\end{array}$ \\
\hline K16 & P2 & $\begin{array}{l}\text { Gempa teranyar terjadi pada pukul 11:48 WIB siang tadi dengan pusat gempa di } \\
79 \text { kilometer barat daya Lebak, Banten, dan kedalaman } 11 \mathrm{~km} \text {. }\end{array}$ \\
\hline K17 & P2 & $\begin{array}{l}\text { Badan Meteorologi Kimatologi dan Geofisika (BMKG) menyebut gempa bumi } \\
\text { terjadi akibat aktivitas subduksi lempeng Indo-Australia ke bawah lempeng } \\
\text { Eurasia. }\end{array}$ \\
\hline K18 & P4 & $\begin{array}{l}\text { Kesimpulan itu diambil dari sejumlah kejadian yang terjadi di sejumlah negara } \\
\text { dihari yang sama, yakni gempabumi 7,9 SR di Alaska, erupsi vulkanis di Filipina, } \\
\text { longsor vulkanis di Jepang, dan terakhir gempabumi 6,1 SR di Lebak, Namun Tirto } \\
\text { menampik kemungkinan tersebut. }\end{array}$ \\
\hline K19 & P5 & $\begin{array}{l}\text { Pertama kita selamatkan jiwanya dulu, sekarang kita berikan bantuan logistic, kata } \\
\text { Bupati Lebak, itu Octavia Jayabaya, saat dikonfirmasi melalui sambungan } \\
\text { teleponnya, Selasa (23/01/2018). }\end{array}$ \\
\hline K20 & P7 & $\begin{array}{l}\text { Berdasarkan informasi yang dihimpun, rumah warga di Kecamatan Bayah dan } \\
\text { Cilograng mengalami pecah kaca, atap hingga tembok ambruk, akibat kencangnya } \\
\text { gempa yang menggoyang wilayah Kabupaten Lebak, Banten. }\end{array}$ \\
\hline K21 & P7 & $\begin{array}{l}\text { Dari semalam kami sudah berkoordinasi dengan pihak provinsi maupun kabupaten } \\
\text { untuk memberikan bantuan, kata Idrus melalui pernyataannya ke media, Rabu } \\
(24 / 1) \text {. }\end{array}$ \\
\hline K22 & P8 & $\begin{array}{l}\text { Di sisi lain, Pemprov Banten juga telah menyalurkan bantuan berupa beras, selimut, } \\
\text { matras, bahan pangan, tenda, dan bantuan lainnya dengan nilai mencapai Rp } 230 \\
\text { juta. }\end{array}$ \\
\hline $\mathrm{K} 23$ & P8 & $\begin{array}{l}\text { Pun, Wakil Gubernur Banten Andika Hazrumy menyatakan tenaga relawan sudah } \\
\text { siap membantu masyarakat Lebak menangani dampak dari gempa bumi Selasa } \\
(23 / 1) \text {. }\end{array}$ \\
\hline
\end{tabular}




\begin{tabular}{|c|c|l|}
\hline K24 & P9 & $\begin{array}{l}\text { Bantuan untuk korban gempa bumi Lebak juga datang dari Polda Banten yang } \\
\text { memberikan aneka bahan pangan, mulai dari beras, gula, telur, hingga bumbu } \\
\text { dapur, biskuit, dan mi instan. }\end{array}$ \\
\hline K25 & P9 & $\begin{array}{l}\text { Selain bantuan bahan pangan, Polda Banten pun menerjunkan satu kompi Brimob } \\
\text { dan satu peleton shabara untuk membantu warga terdampak gempa bumi. }\end{array}$ \\
\hline
\end{tabular}

Proses selanjutnya seperti diperlihatkan dalam Tabel 8, Tabel 9.

Tabel 8 Proses perhitungan TF gabungan dari ringkasan kalimat gabunga dari kedua dokumen

\begin{tabular}{|c|c|c|c|c|c|c|c|c|c|c|c|}
\hline \multirow{2}{*}{ No } & \multirow{2}{*}{ Term } & \multicolumn{9}{|c|}{ TF } & \multirow{2}{*}{ idf } \\
\hline & & K1 & K2 & K3 & K4 & K5 & K6 & K7 & $\ldots$ & K25 & \\
\hline 1 & tribunnews & 1 & & & & & & & & & 9 \\
\hline 2 & Com & 1 & & & & & & & & & 1 \\
\hline 3 & Jakarta & 2 & & & & 1 & & 1 & & & 2 \\
\hline 4 & Gempa & 1 & 1 & 1 & 1 & 2 & & & & 1 & 12 \\
\hline 5 & Bumi & 1 & & & & & & & & 1 & 2 \\
\hline 6 & Landa & 1 & & & & & & & & 1 & 1 \\
\hline 7 & Banten & 1 & & 1 & 1 & 1 & & 1 & & & 2 \\
\hline 8 & Selasa & 1 & & & & 1 & & & & & 4 \\
\hline 12 & Sekitar & 1 & 1 & & & & & & & & 1 \\
\hline 13 & Pukul & 1 & 1 & & & & & & & & 6 \\
\hline 16 & Wib & 1 & 1 & & & & & & & & 4 \\
\hline
\end{tabular}

Tabel 9 Proses perhitungan wdt ringkasan dari kalimat-kaliamt gabungan kedua dokumen

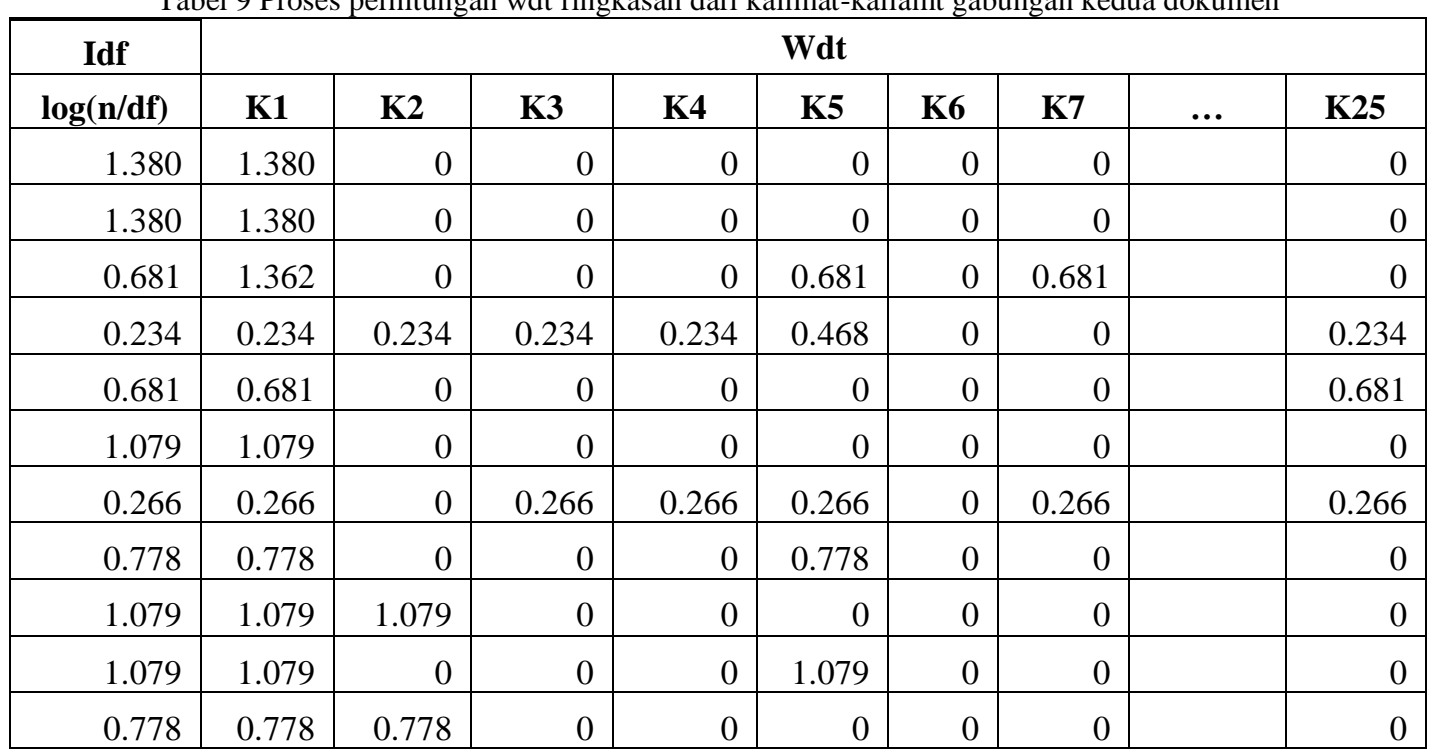


Setelah bobot setiap kaliamt diurutkan, kemudian menentukan tingkat kompresi ringkasan didapat beberapa kalimat dengan bobot terbesar. Kemudian gabungkan dan susun kembali berdasarkan urutan kalimat pada dokumen.

Rumus menentukan tingkat kompresi :

Rate = Jumlah kalimat $-($ Jumlah kalimat $* \mathrm{~N} \%)$

$=25-(25 * 75 \%)$

$=25-18,75$

$=6,25$ "dibulatkan menjadi 6 kalimat"

Jadi didapat hasil ringkasan dengan tingkat kompresi $75 \%$ yaitu 6 kalimat terdiri dari K1, K5, K6, K8, K15, K18. Hasil ringkasan dapat dilihat di Tabel 10.

Tabel 10 Hasil peringkat disusun sesuai kalimat

\begin{tabular}{|c|c|c|}
\hline No & Kalimat & Kalimat \\
\hline 4 & K1 & $\begin{array}{l}\text { Terjadi } 35 \text { kali gempa susulan setelah gempa utama berkekuatan } \\
6,1 \text { skala richter dirasakan warga Banten, termasuk Jakarta, } \\
\text { bekasi, Bogor, serta Sumatera bagian selatan, Selasa }(23 / 1 / 2018) \text {. }\end{array}$ \\
\hline 5 & K5 & $\begin{array}{l}\text { Atau tepatnya berlokasi di laut pada jarak } 72 \mathrm{~km} \text { Barat Daya } \\
\text { Lebak-Banten pada kedalaman } 44 \mathrm{~km} \text {, ujar Kepala Pusat } \\
\text { Gempabumi dan Tsunami BMKG, Moch Riyadi dalam } \\
\text { keterangannya, Rabu }(24 / 1 / 2018) \text {. }\end{array}$ \\
\hline 2 & K6 & $\begin{array}{l}\text { Sebelumnya, data sementara yang diperoleh dari BPBD Lebak, } \\
\text { setidaknya sudah } 45 \text { rumah rusak, yaitu masing-masing } 3 \text { rumah di } \\
\text { Kecamatan Bayah, } 1 \text { rumah di Kecamatan Wanasalam, } 32 \text { rumah } \\
\text { di Kecamatan Panggarangan, } 6 \text { rumah di Kecamatan Cilograng, } 1 \\
\text { rumah di Kecamatan Lebak Gedong, dan } 2 \text { rumah di Kecamatan } \\
\text { Sobang. }\end{array}$ \\
\hline 1 & K8 & $\begin{array}{l}\text { Sebagai bentuk kepedulian kepada sesama, hari ini relawan Jokowi } \\
\text { (ABJ) menyerahkan bantuan berupa keperluan yang dibutuhkan } \\
\text { warga korban gempa Lebak, terang Ketua Umum Dewan Pengurus } \\
\text { Pusat Arus Bawah Joko Widodo (DPP ABJ) Veldy Reynold dalam } \\
\text { keterangannya, Sabtu (27/1/2018). }\end{array}$ \\
\hline 6 & K15 & $\begin{array}{l}\text { Dari kemarin sejak gempa pertama sudah } 47 \text { kali, tapi makin lama } \\
\text { makin kecil, kata Kepala Badan Penanggulangan Bencana Daerah } \\
\text { (BPBD) Kabupaten Lebak, Kaprawi, Jumat }(26 / 1) \text {. }\end{array}$ \\
\hline 3 & K18 & $\begin{array}{l}\text { Kesimpulan itu diambil dari sejumlah kejadian yang terjadi di } \\
\text { sejumlah negara dihari yang sama, yakni gempabumi 7,9 SR di } \\
\text { Alaska, erupsi vulkanis di Filipina, longsor vulkanis di Jepang, dan } \\
\text { terakhir gempabumi } 6,1 \mathrm{SR} \text { di Lebak, Namun Tirto menampik } \\
\text { kemungkinan tersebut. }\end{array}$ \\
\hline
\end{tabular}




\section{Hasil}

Aktivitas persiapakan membuat resume multidokumen, dimulai dengan mengambil dokumen masing-masing seperti pada Gambar 1. Hasil ringkasan masing-masing dokuemn diperlihatkan dalam Gambar 2. Setelah digabungkan hasil ringkasan dari dokumen pertama dan kedua seperti pada Gambar 3, hasil resume dari dokumen gabungan adalah resume dari dokumen multi dokumen seperti pada Gambar 4. Pengujian dilakukan menggunakan uji responden dan uji kemiripan[3].

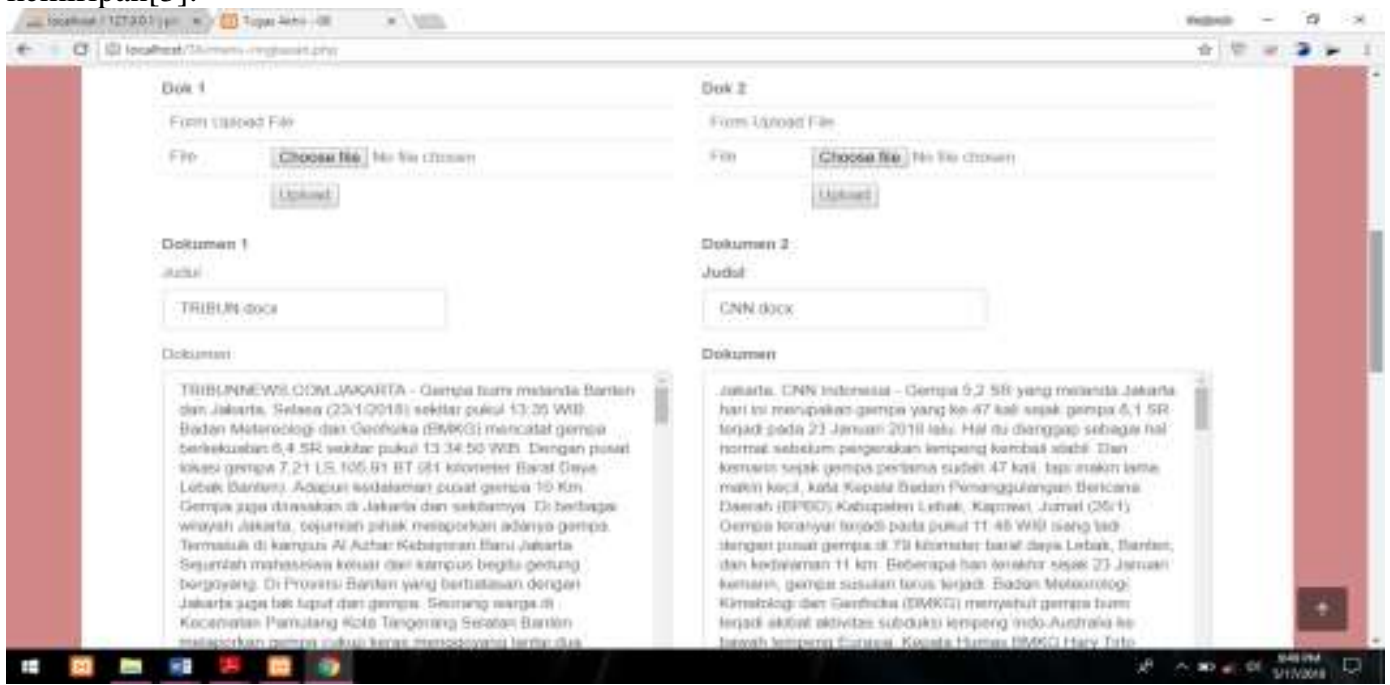

Gambar 1 Halaman peringkas teks

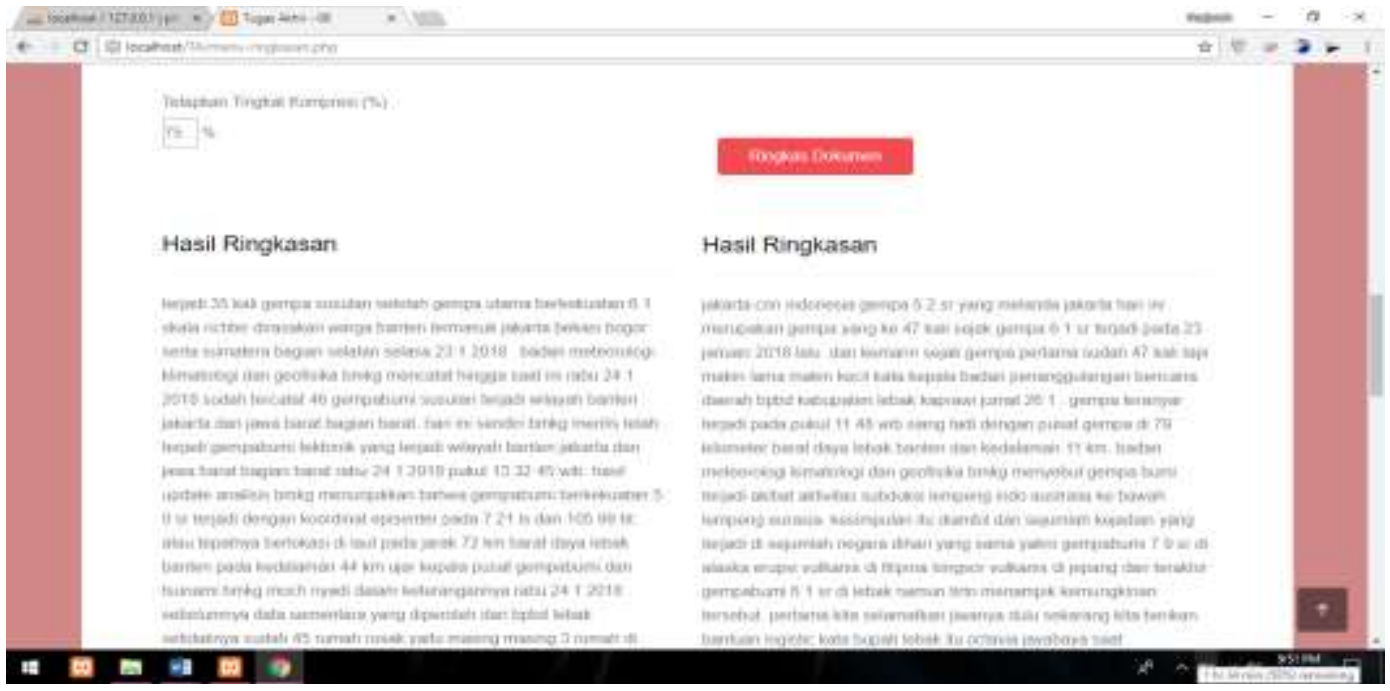

Gambar 2 ,Hasil ringkas tahap 1 


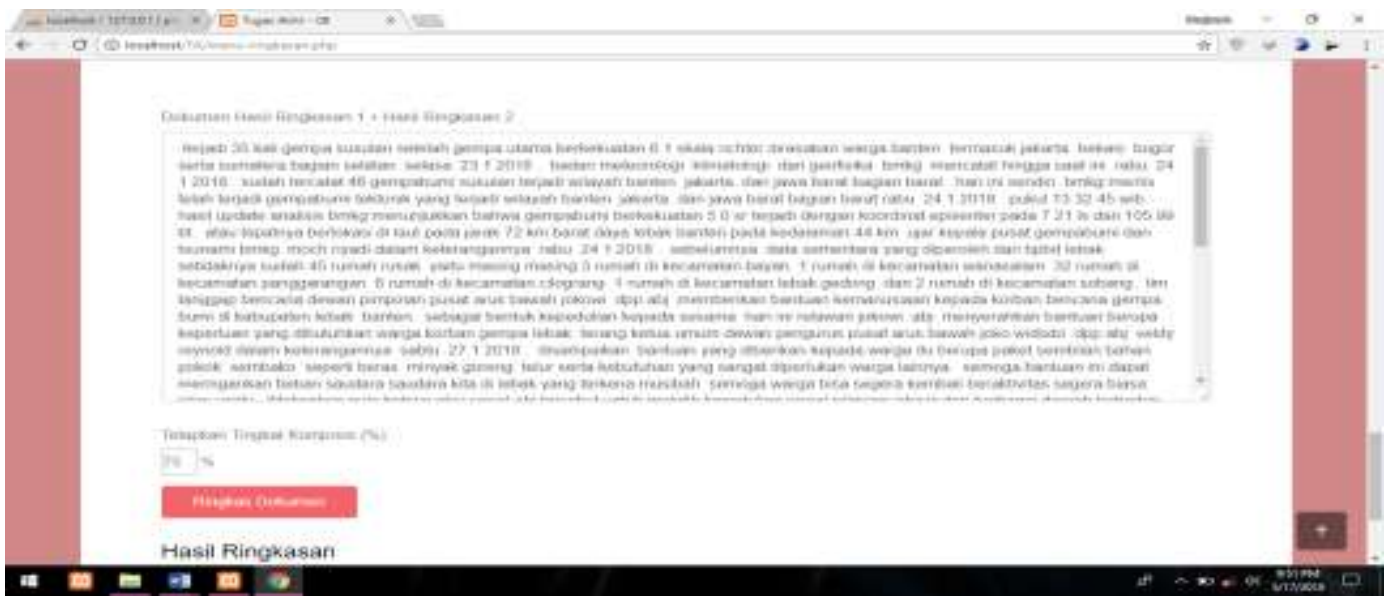

Gambar 3 Ringkas tahap 2

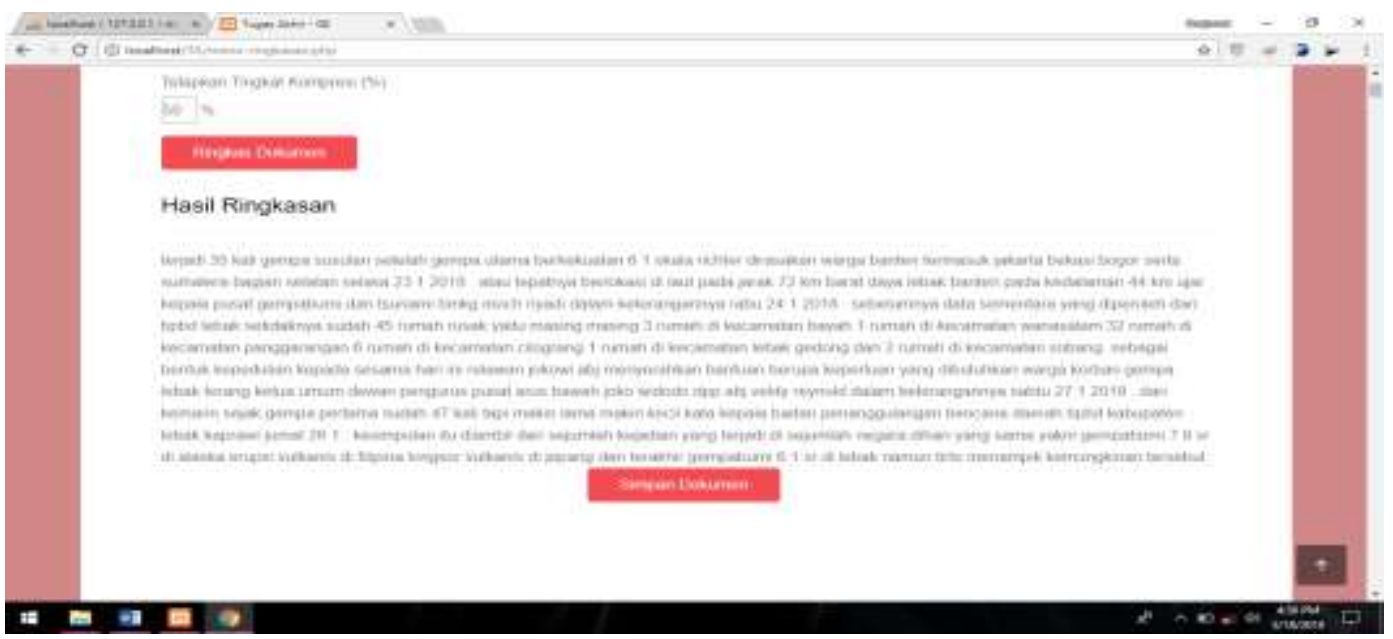

Gambar 4 Ringkas tahap 3

\section{Kesimpulan}

Dapat diimplementasikan system peringkas teks multi dokumen, dengan minimal dua dokumen artikel berita gempa dari dua harian nasional, Sistem ini dapat membantu mengetahui isi penting dari kliping artikel berita multi dokumen dan memiliki akurasi hasil uji responden $54.45 \%$ dan uji kemiripan dokumen sebesar 78.023\%.

\section{Daftar Pustaka}

[1] M. Allahyari et al., "Text Summarization Techniques: A Brief Survey," Int. J. Adv. Comput. Sci. Appl., vol. 8, no. 10, 2017.

[2] F. Hendy Evan and Y. W. Sigit Purnomo, "Pembangunan Perangkat Lunak Peringkas Dokumen dari Banyak Sumber Menggunakan Sentence Scoring dengan Metode TF-IDF," Semin. Nas. Apl. Teknol. Inf. Yogyakarta, vol. 21, no. 17, pp. 1907-5022, 2014.

[3] A. Z. Z. Abidin and E. Y. Rayi, "PERINGKAS TEKS OTOMATIS DOKUEM TUNGGAL DAN MULTI BAHASA MENGGUNAKAN METODE TF-IDF," 2019.

[4] A. Z. Z. Abidin, Y. Murdianingsih, U. T. Suryadi, and D. Setiyadi, "TEXT SUMMARIZING 
SYSTEM OF ENGLISH SUBJECTS AND TEXT MINING SUBJECTS,” vol. 7, no. 5, pp. 730-742, 2020.

[5] W. Yulita, S. Priyanta, and A. SN, "Automatic Text Summarization Based on Semantic Networks and Corpus Statistics,” IJCCS (Indonesian J. Comput. Cybern. Syst., vol. 13, no. 2, p. 137, 2019.

[6] V. Amrizal, "Penerapan Metode Term Frequency Inverse Document Frequency (Tf-Idf) Dan Cosine Similarity Pada Sistem Temu Kembali Informasi Untuk Mengetahui Syarah Hadits Berbasis Web (Studi Kasus: Hadits Shahih Bukhari-Muslim),” J. Tek. Inform., vol. 11, no. 2, pp. 149-164, 2018.

[7] N. Hayatin, C. Fatichah, and D. Purwitasari, "Trending Issue Untuk Peringkasan Multi Dokumen," vol. 13 , pp. $38-44,2015$.

[8] A. Widiantoro, "Peringkasan Teks Otomatis Pada Dokumen Berbahasa Jawa Menggunakan Metode Tf-Idf," 2014 